\title{
Translating “Muhammad Al-Fatih: Perang Varna” Into English
}

\author{
Zakiah mahmudah $^{1}$, Hasbi $^{2}$, Difiani Apriyanti ${ }^{3}$ \\ ${ }^{2}$ English Department, Politeknik Negeri Padang, Limau Manis, Padang, Indonesia \\ hasbi_nian@yahoo.com \\ ${ }^{3}$ English Department, Politeknik Negeri Padang, Limau Manis, Padang, Indonesia \\ difiani.apriyanti@yahoo.com
}

\begin{abstract}
This final report explains about the process of comic book translation that the title of comic book is "Muhammad al-Fatih: Perang Varna" which was created by Handri Satria an illustrator from Indonesia. This final project is entitled Translating "Muhammad Al-Fatih: Perang Varna" Comic by Handri Satria from Bahasa Indonesia into English which this final project is one of the requirements for the students of English Department in State Polytechnic of Padang in order to finish their study. This final project is aimed to add the reference of translating a comic. This final report gave the discussion of processes or steps that have to be passed so that the result of translation can be understood easily by the readers. By making this final project, it is quite helpful in applying and comprehending the theories of translation that had been learned. After finishing this final project, it can be concluded that to translate texts the translator must have the adequate vocabularies and wide insight either in specific knowledge or in general knowledge, because the translator's role is to make people understand the ideas and the meaning of text.
\end{abstract}

Keywords - Comic book; comic translation; process of comic translation; The battle of Varna.

\section{INTRODUCTION}

In this modern era, internet serves people with many information that they need. Due to the presence of internet, people can access various information included a book that have been served in electronic form wherethis book can be accsessed and read through our smart gadget anywhere. Since along ago, the people have readbooks ingettingand collectingthe information. This habit is still continued till now, albeit internet has provided the electronic book to be read, yet the printed books still become the main choice for the people in getting and collecting information. Some people say that holding the printed books to be read is more comfortable than holding the electronic books. As we know, so many types of books are really famous that are read by people. One of them is comic book.

Comic is an entertaining book that allows readers to read and escape from the real world into a fantasy. So many kinds of comics that is available such as comic book and comic strip. Comic books show pictures and text interactions which are funny or amusing. Comic can be part of a newspaper that has comic strip. Comic strip is series of pictures that are drawn inside boxes and tell a story. This final project focuses on comic book. So, comic book is desirable among children up to teenagers and even adults since it contains attractive pictures. Most of people like and enjoy in reading comic.

Muhammad Al-Fatih: Perang Varna is a famous comic book in Indonesia which was written by Handri Satria and published in 2016 by Salsabila Pustaka Al-Kautsar Grup publisher. The story tells about the history of conquering Constantinople. It is a true story that happened on Turk land. Constantinople which is located between two oceans and two continents was a glorious city at that time. So many countries wanted to occupy it. Yet, during thousands years, it stood sturdily and always defended from all of outside attacks. At last Constantinople was conquered by Sultan Muhammad al-Faateh in 1453, after doing a long preparation since 1349 .

The story of this comic tells about a great planning, great preparation and also contains about moral value that can be known from the struggle of Islam in conquering the Constantinople city. The lesson of this story also gives the readers good inspiration, motivation, and also telling a sacrifice in getting a victory.

This book tells the great history that was done by Moslem in an interesting way by using attractive pictures. By having the English version, the comic can be enjoyed not only by readers of Indonesian, but also western people.

Having this title as the final project, it will add the reference for the English Department especially in 
translation class, because doing a comic translation is different from doing general translation. So, this final project is very important. The comic translated, wraps the history of Muhammad al-Faateh through interesting visuals and the description at that time. It makes the readers easily understand about the content and value that is explained in the comic, by reading and seeing the pictures in the comic which is the reflection of the condition during that time. Therefore, in translating this comic, the atmosphere of comic "Muhammad al-Fatih: Perang Varna" must be brought into target language in order to make the readers understand and feel the sense during reading it.

\section{METHOD}

This part presents the explanation of the processes, methods, and procedures that were used in translating the Muhammad al-Fatih comic. This final project discussed about the process of translating Muhammad al-Fatih: Perang Varna comic that was written by Handri Satria from Indonesia. The number of word in source text to be translated is 3.869 words in 153 pages. This comic was inspired based on true story that happened on Turk land. It tells about the preparation to conquer the Constantinople city (Istanbul today). The purpose of translating this comic is to help the foreign reader who cannot understand Bahasa Indonesia in reading this comic. There were some steps of translating this comic.

The process of translating comic that is proposed by Ashobta Azry consists of five steps namely scan, raw, clean, translate, and typeset. The first three steps are skipped, because, the soft-file of comic is already available before. So, it is not necessary to do the scan, raw, and clean process, because it had been done by the publisher. It is then continued to the translating and typesetting process as the next steps in translating comic.

\section{Translating Process}

So, the first step was the translation of texts that were contained in the comic. This comic was translated from Bahasa Indonesia into English. In translating comic, the process of translation that used is mentioned by Newmark (1988) namely The interpretation and analysis of the SL text, The translation procedure, and The reformulation of text.

The interpretation and analysis of the SL text. In this first process of translation, it was began with retyping the text first. After retyping, then read the whole text for three or five times in order to make more comprehend about the story. After read several times, it could be decided how the language style of author and who is the target reader of the comic. By reading and seeing the comic, it was quite easy to decide who is the target reader, because the comic tells about a history in Islam.

The translation procedure. The translation procedures were also needed to make the target language understandable and acceptable by the reader. The procedures of translation were used that stated by two experts namely Newmark (1988:81) and Vinay and Darbelnet (1956).

The reformulation of text. At this phase, after analyzing the text had been done and translated using some procedures, the text was reformulated into the good target language that appropriate with the writer's intention.
In translating the comic was also used a method of translation. The method that used was the Adaptation by Newmark (1988). The reason in choosing this method, because of this method is closer to the target language and also it is used for comedies and poetry; the themes, characters, plots are usually preserved, the SL culture is converted to the TL culture and the text rewritten. Therefore, this method is more suitable in translating comic, because comic is included into the comedies type. Then, when the translation was conducted the SL and TL was inserted into the same table but different column in order to make the translation activity fast and easy. It can be seen on Picture 1 below.

Picture 1.

The text translation

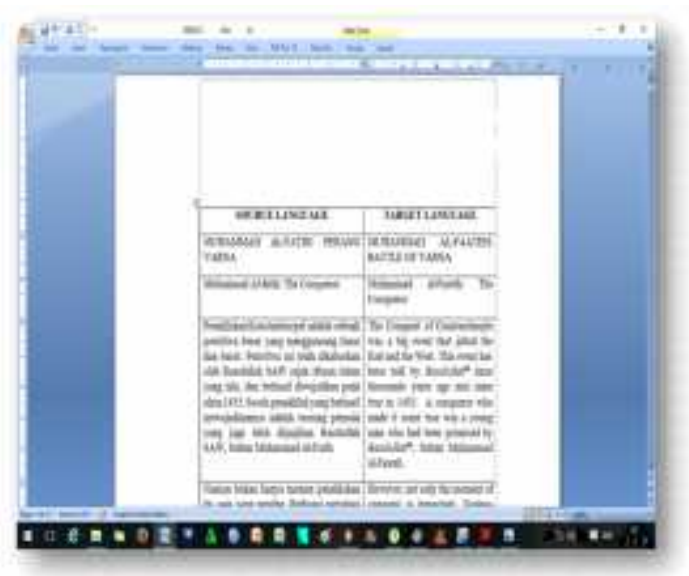

After translating the comic, there are some friends who were asked as the proofreader to check the result of the translation. The proofreaders also gave some corrections on the translation result. The proof readers were the supervisors, and friends. Friends who helped were Haby Syauqi and Feldi Sandria. The reason to ask their help in giving correction is because both of them have a good language style in English literary especially for comic book type and this is really helpful in making better the result of translation. Beside of that, both of them also have good grammar skill in checking the grammar mistake in English. Their help was really useful in making a good translation result. After all, the result of translation was read again for several times because to translate correctly it is necessary to check it for many times.

\section{Typesetting Process}

After the translating process, it was continued to the typesetting process in translating comic. In typesetting, some software applications were also used to help in doing typeset. The software applications that used were PhotoScape 3.6.5, Paint 1511, and PhotoShop CS6. Those software applications were used to edit the soft-comic from Bahasa Indonesia version became English version. In typesetting process, it was used the PhotoScape 3.6.2software applicationand used the Comic Sans font with the font size is 26pts, it was typed with uppercase style.So, following steps are the way how to do the typesetting process.

For the first step in doing typeset, open the software application. After the application is opened, the window appears showing many tools or icons that have their own 
function. To continue the step to do typesetting, then click the Editor tool or the Camera icon. It can be seen on Picture 2.

Picture 2.

PhotoScape Software Application

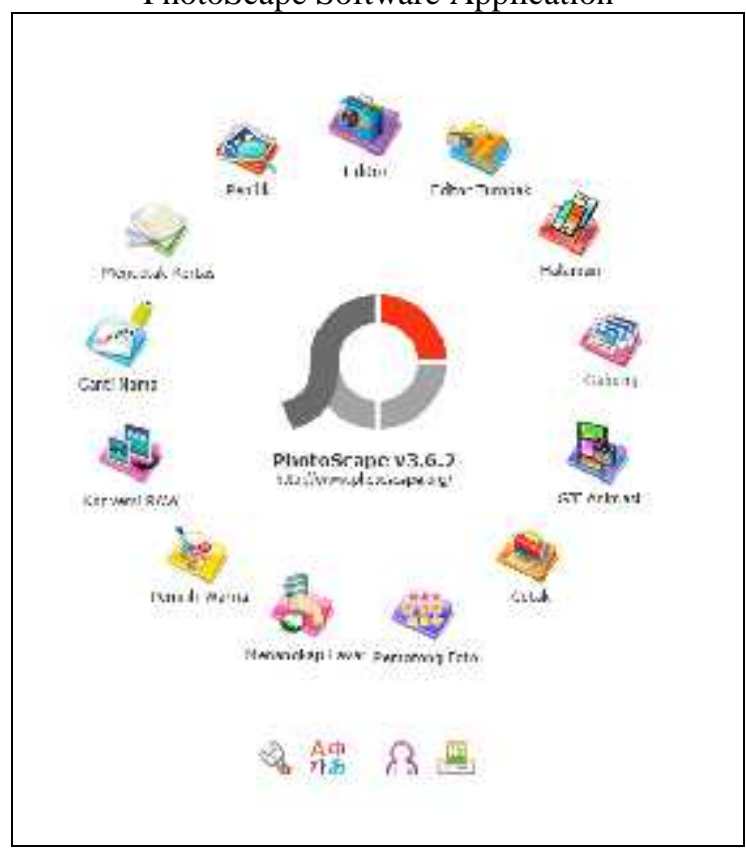

After clicked the Editor tool, the next window will appear. It can be seen like on the Picture 3 below.

Picture 3.

The work layout

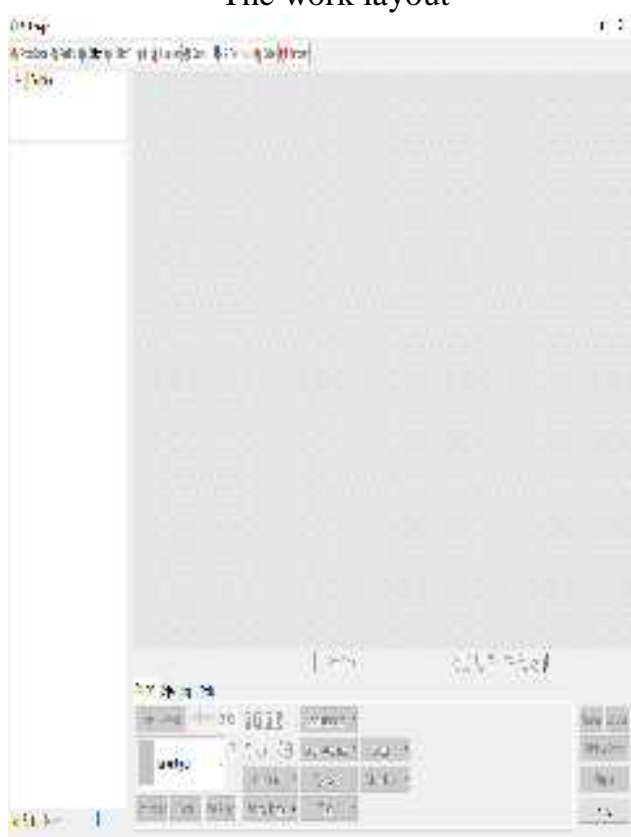

The second step, choose the directory where the pictures are saved. Just click the name of the directory of file so that the pictures can appear on the column as can be seen on the Picture 4.

Picture 4.

The directory of file

Dxisi:x

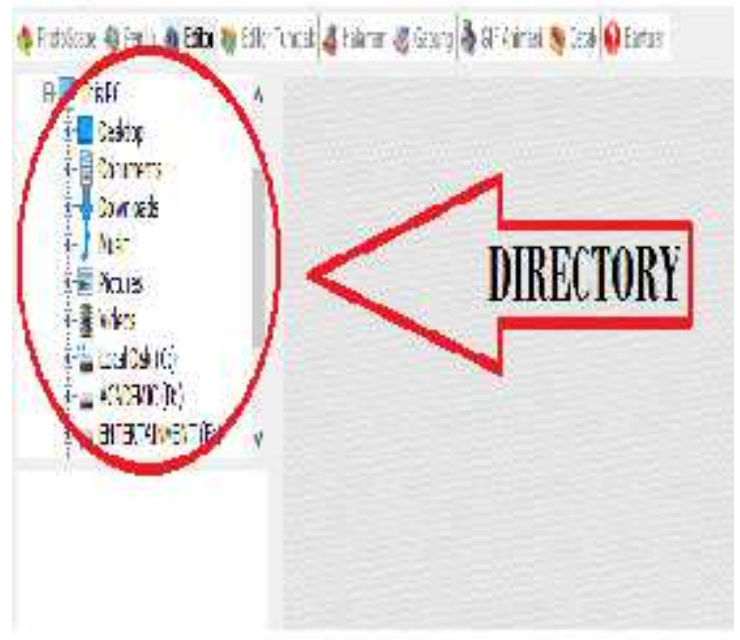

The third step, after the directory had been chosen, then the pictures appear on the column. Next, click the picture that will be edited. After the picture was chosed, the picture will appear on the Drawing window. It can be seen like on the Picture 5 below.

Picture 5.

The picture appears

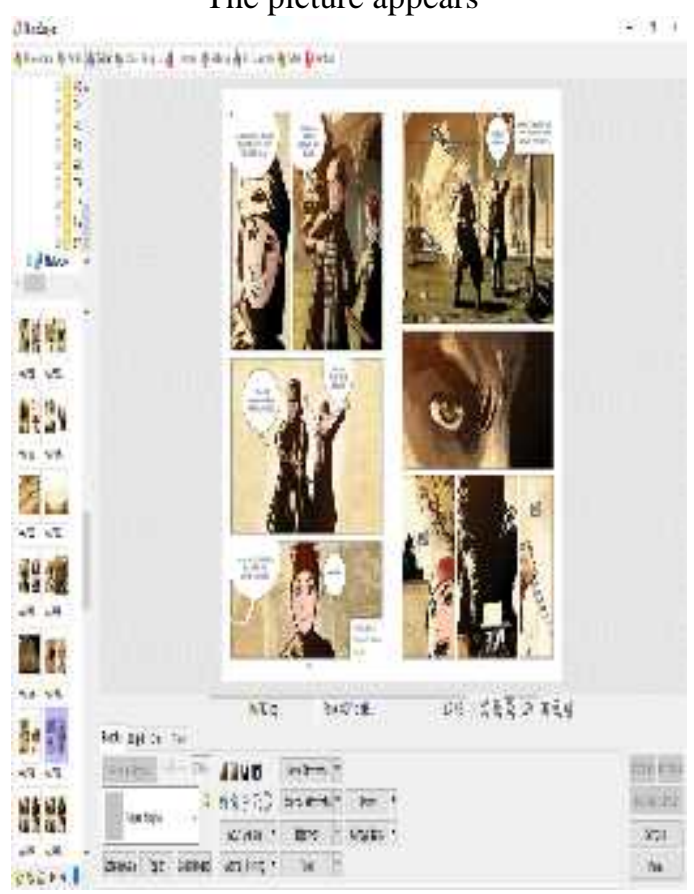


The fourth step is after the picture appeared, the next is continued to edit the picture. There is a Tool button in the Buttom Bar. Click the Tool button till shows the menu as can be seen on the Picture 6 below. Those menus can be used to edit the picture.

Picture 6.

The tools to typeset

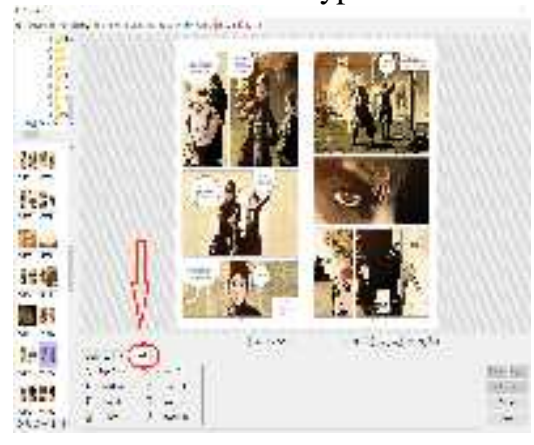

As can be seen on the Picture 7 below, picture on the left side is before edited and picture on the right side after edited.

Picture7.

The comparison result.

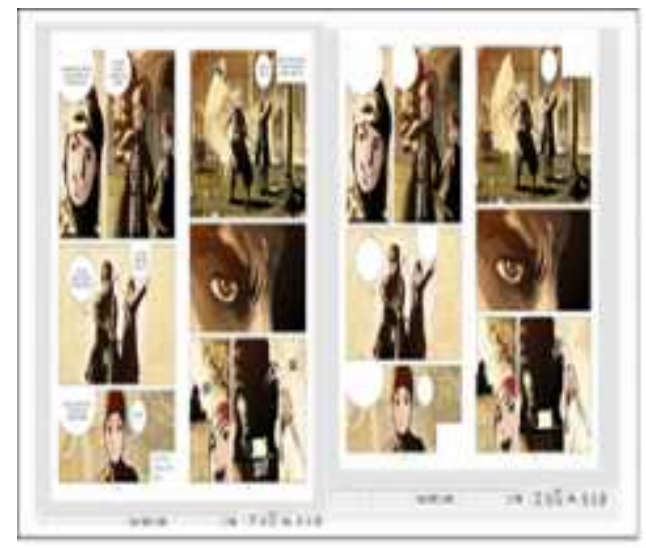

After the speech balloons have been cleared, the next is continued to fill the speech balloons with the new text. The result as can be seen like on the Picture 8 below.

Picture 8.

Bahasa Indonesia version and English version

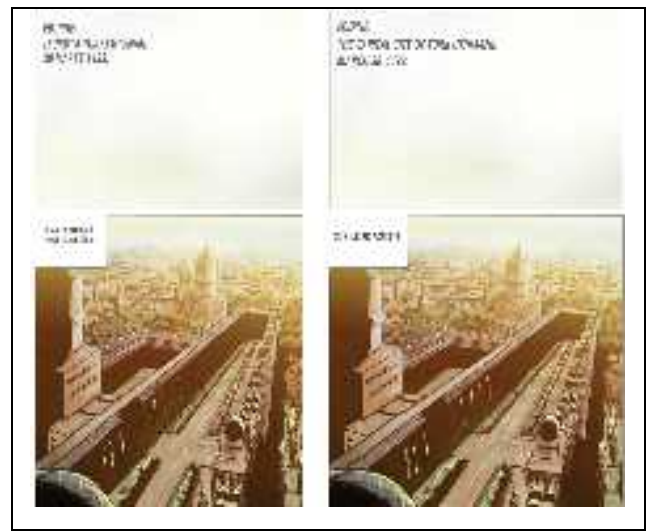

\section{Process of Translating the Comic}

In translating the comic, the process of translation which is mentioned by Ashobta Azry namely Scan, Raw, Clean, Translate, and Typeset were used. As the soft-file of the comic is already available, then the first three steps are skipped. Therefore, it was continued to the next steps to translate the texts of comic from the source language (Bahasa Indonesia) into the target language (English). Then, for the next section, the Translating process and the Typesetting process were explained in detail.

The translating process. To translate the comic, it must pass the process of translation, in order to make the result of translation more directed and structured well. In the translating process, it was used the process of translation that stated by Newmark (1988) namely the interpretation and anlysis of the SL text, the translation procedure, the reformulation of text.

The interpretation and anlysis of the SL text. In analyzing process, the source text was analyzed about what is the purpose and who is the target reader that is aimed by the author. The author of Muhammad al-Fatih: Perang Varna comic is Handri Satria. He is a comic writer from Indonesia. To know how the author's language style, then it can be found by reading other comic written by the same writer.

Beside of that, Handri Satria's purpose in writing this comic is to add the reference of Islamic comic that can give a lesson for the readers. By writing this comic he also wanted to decsribe the great people in Islam. So, it can be concluded that the target reader of this comic that is aimed by Handri Satria namely the kids, the teenagers, even the adults and by having the comic in English version, it can decide that the target reader is the western kids, western teenagers, western adult and also for the people that understand English. The obstacle of doing this process was when decided how the language style of the author, therefore to solve this problem, it was necessary to read another book of author.

The comic was written in Bahasa Indonesia that tells about true story which is based on the history that happened on Turk land. As this comic is a comic book type, therefore it was used the present and past tense in translating. The example of Present and Past Tense using, it can be seen in the Table 13 below 
Table 13.

The example of using present and past tense

\begin{tabular}{|c|c|}
\hline Present Tense & Past Ter \\
\hline SL: Hey, cepat bangu & SL: \\
\hline & Konstantin \\
\hline ada & adalah \\
\hline $\begin{array}{l}\text { cari! } \\
\text { TL: Hey }\end{array}$ & \\
\hline $\begin{array}{l}\text { Sehzade Mehmed is } \\
\text { not in his room. Find } \\
\text { quickly! }\end{array}$ & $\begin{array}{l}\text { TL: The Conquest } \\
\text { of Constantinople } \\
\text { was a big event. }\end{array}$ \\
\hline
\end{tabular}

In the example of Present tense above, it shows that there is the "is" as the verb for the singular subject in the nominal sentence. It also indicates the conditional when the situation happens at the time of the story. Then, it can be seen from the example of Past tense that there is the "was" as the verb for the singular subject in the past tense in the nominal sentence. It indicates the conditional when the event had passed before it is written or spoken.

The translation procedure. In translating the comic content, the procedures that used were mentioned by Newmark (1988) namely Transference, Naturalisation, Culture equivalent, Functional equivalent, Shifts or transpositions, Modulation, Compensation, Reduction and expansion, Notes, Synonymy, and also Equivalence by Vinay and Darbelnet (1956).

Transference. This procedure is used when the translator uses the word from SL (source language) then become a loan word in TL (target language). This procedure was used for the word that describe about name of person/place/noun. The purpose of using this procedure is in order to make the reader can feel the sense of the original situation while reading, because this comic has a specific culture. There are 21 samples that used the Transference procedure. The following table is the sample list of using the Transference procedure. It can be seen on the Table 14 below.

Table 14

The example of using Transference procedure

\begin{tabular}{|c|c|c|}
\hline No. & Source Language & Target Language \\
\hline 1. & Rasulullah & Rasulullah \\
\hline 2. & Allah & Allah \\
\hline 3. & Marmara & Marmara \\
\hline 4. & Sehzade & Sehzade \\
\hline 5. & Yildirim & Yildirim \\
\hline 6. & Bulgaria & Bulgaria \\
\hline 7. & Macedonia & Macedonia \\
\hline 8. & Serbia & Serbia \\
\hline 9. & Ankara & Ankara \\
\hline 10. & Alhamdulilah & Alhamdulilah \\
\hline 11. & Subhanallah & Subhanallah \\
\hline 12. & Walhamdulilah & Walhamdulilah \\
\hline 13. & Sultan Murad II & Sultan Murad II \\
\hline 14. & Edirne & Edirne \\
\hline 15. & Amasya & Amasya \\
\hline 16. & Manisa & Manisa \\
\hline
\end{tabular}

\begin{tabular}{|c|c|c|}
\hline 17. & Bursa & Bursa \\
\hline 18. & Ma'qul & Ma'qul \\
\hline 19. & Manqul & Manqul \\
\hline 20. & Polymath & Polymath \\
\hline 21. & Bisyarah & Bisyarah \\
\hline
\end{tabular}

Naturalisation. It is used when the translator tranfers the word from SL (source language) into TL (target language) based on the first pronunciation. There are 17 samples that used this procedure. The following table is the sample list of using this procedure. It can be seen on the table 15 as follows.

Table 15.

The example of using Naturalization procedure

\begin{tabular}{|c|c|c|}
\hline No. & Source Language & $\begin{array}{c}\text { Target } \\
\text { Language }\end{array}$ \\
\hline 1. & Muhammad al-fatih & $\begin{array}{c}\text { Muhammad al- } \\
\text { faateh }\end{array}$ \\
\hline 2. & Ghazi & Gazi \\
\hline 3. & Konstantinopel & Constantinople \\
\hline 4. & Theodosius & Theodosian \\
\hline 5. & Bayazid & Bayezid \\
\hline 6. & Turki Usmani & Turk Uthmani \\
\hline 7. & Polandia & Poland \\
\hline 8. & Jagiello & Jagiellonian \\
\hline 9. & Vladislaus & Vladislav \\
\hline 10. & Kardinal & Cardinal \\
\hline 11. & Kristendom & Christiandom \\
\hline 12. & Syaikh & Shaykh \\
\hline 13. & Ahmet & Ahmed \\
\hline 14. & Strategi & Strategy \\
\hline 15. & InsyaaAllah & InshaaAllah \\
\hline 16. & Syariat & Syiariah \\
\hline 17. & Zaganosh & Zagan \\
\hline
\end{tabular}

Shifts or transpositions. It is used when the translation that involving a change in the grammar from SL to TL. There are 20 samples that used this procedure. The following table is the sample list of using this procedure. It can be seen on the Table 16 as follows.

Table16.

The example of using Shifts or transpositions procedure

\begin{tabular}{|l|l|l|}
\hline No. & \multicolumn{1}{|c|}{ Source Language } & \multicolumn{2}{|c|}{ Target Language } \\
\hline 1 & $\begin{array}{l}\text { Konstantinopel, sebuah kota } \\
\text { yang diimpikan dunia. }\end{array}$ & $\begin{array}{l}\text { Constantinople is } \\
\text { city that the } \\
\text { world dreams of. }\end{array}$ \\
\hline 2 & Cita-citaku tinggi! & $\begin{array}{l}\text { My ambition is } \\
\text { high. }\end{array}$ \\
\hline 3. & $\begin{array}{l}\text { Edirne, Ibukota Turki Usmani. } \\
30 \text { Maret 1432. }\end{array}$ & $\begin{array}{l}\text { Edirne, The } \\
\text { capital city of } \\
\text { Turk Uthmani. } \\
\text { March 30, 1432. }\end{array}$ \\
\hline
\end{tabular}

Reduction and expansion. It is used when the translation has to reduce or even expand the text in the SL to TL. There are 17 samples that used this procedure. The 
following table is the sample list of using this procedure. It can be seen on the Table 17 below.

Table 17.

The example of using Reduction and expansion procedure

\begin{tabular}{|c|c|c|}
\hline No. & Source Language & Target Language \\
\hline 1. & $\begin{array}{l}\text { Bagaimana proses } \\
\text { terbentuknya sosok } \\
\text { seorang Muhammad al- } \\
\text { Fatih hingga menjadi } \\
\text { sosok penkhluk yang } \\
\text { dijanjikan, amatlah } \\
\text { menarik untuk ditelusuri. }\end{array}$ & $\begin{array}{l}\text { How was the process } \\
\text { of Muhammad al- } \\
\text { Faateh to become the } \\
\text { conqueror who had } \\
\text { promised very } \\
\text { interesting story to } \\
\text { be explored. }\end{array}$ \\
\hline
\end{tabular}

Note. It is used when the translation needs to supply a additional information in a translation. There are 2 samples that used this procedure. The following table is the sample list of using this procedure. It can be seen on the Table 18 below.

Table 18.

The example of using Note procedure

\begin{tabular}{|c|c|c|}
\hline No. & Source Language & Target Language \\
\hline 1. & $\begin{array}{l}\text { Didiklah mereka menjadi } \\
\text { Ghazi }^{1} \text {. } \\
\text { Ghazi }^{1} \text { adalah sebuah } \\
\text { sebuah sebutan bagi } \\
\text { ksatria islam. Sultan- } \\
\text { sultan turkey } \\
\text { ustmanipun bergelar } \\
\text { Ghazi) }\end{array}$ & $\begin{array}{l}\text { Educate them } \\
\text { Gazi }^{1} \text {. } \\
\left(\text { Gazi }^{1} \text { is a title }\right. \\
\text { for knight of } \\
\text { Islam. } \\
\text { sultans of Turk } \\
\text { Uthmani were } \\
\text { also titled Gazi } \\
\text { too.) }\end{array}$ \\
\hline 2. & $\begin{array}{l}\text { Hey, cepat bangun, } \\
\text { Sehzade }^{2} \text { Mehmet tidak } \\
\text { ada dikamarnya. Cepat } \\
\text { cari! ('Sehzadeberarti } \\
\text { pangeran) }\end{array}$ & $\begin{array}{l}\text { Hey, get up, } \\
\text { Sehzade }^{2} \\
\text { Mehmed is not in } \\
\text { his room. Find } \\
\text { quickly! } \\
\text { ('Sehzademeans } \\
\text { prince) }\end{array}$ \\
\hline
\end{tabular}

Synonymy. It is used when the SL text that not clear enough if translate one to one equivalent into TL text. There are three samples that used this procedure. The following table is the sample list of using this procedure. It can be seen on the Table 19 below.

Table 19.

The example of using Synonymy procedure

\begin{tabular}{|c|l|l|}
\hline No. & \multicolumn{1}{|c|}{ Source Language } & \multicolumn{1}{|c|}{ Target Language } \\
\hline 1. & $\begin{array}{l}\text { Bagaimana caranya } \\
\text { memantaskan diri, }\end{array}$ & $\begin{array}{l}\text { How to improve } \\
\text { himself, }\end{array}$ \\
\hline
\end{tabular}

Functional Equivalent. It is used when to apply the cultural words, requires the use of a culture-free word, sometimes with new specific term. There is one sample that used this procedure. The following table is the sample list of using this procedure. It can be seen on the Table 20 below.

Table 20.

The example of using Functional Equivalent procedure

\begin{tabular}{|c|c|l|}
\hline No. & Source Language & \multicolumn{2}{|c|}{ Target Language } \\
\hline 1. & Kesultanan Turki Usmani & $\begin{array}{l}\text { Turk Uthmani } \\
\text { Sultanate }\end{array}$ \\
\hline
\end{tabular}

Modulation. It is used when changing of viewpoint, of perspective and very often of category of thought. There are eleven samples that used this procedure. The following table is the sample list of using this procedure. It can be seen on the Table 21 below.

Table 21.

The example of using Modulation procedure

\begin{tabular}{|c|l|l|}
\hline No. & \multicolumn{1}{|c|}{ Source Language } & \multicolumn{2}{c|}{ Target Language } \\
\hline 1. & $\begin{array}{l}\text { Anakku, kelak kau } \\
\text { akan menjadi raja apa } \\
\text { yang kau cita-citakan } \\
\text { saat naik tahta? }\end{array}$ & $\begin{array}{l}\text { My son, what kind } \\
\text { of king do you } \\
\text { aspire when you } \\
\text { ascend the throne } \\
\text { later? }\end{array}$ \\
\hline 2. & $\begin{array}{l}\text { Kau akan menjadi raja } \\
\text { yang membanggakan! }\end{array}$ & $\begin{array}{l}\text { You will be a proud } \\
\text { king! }\end{array}$ \\
\hline
\end{tabular}

Compensation. It is usedwhen loss of meaning, sound effect, metaphor or pragmatic effect in one part of a sentence is compensated in another part, or in contiguous sentence. There is one sample that used this procedure. The following table is the sample list of using this procedure. It can be seen on the Table 22 below.

Table 22.

The example of using Compensation procedure

\begin{tabular}{|l|lr|l|}
\hline No. & \multicolumn{2}{|c|}{ Source Language } & \multicolumn{1}{c|}{ Target Language } \\
\hline 1. & $\begin{array}{l}\text { Musuh bisa saja } \\
\text { mengintai dari balik } \\
\text { bayang-bayang. }\end{array}$ & $\begin{array}{l}\text { Perhaps, the enemy } \\
\text { is lurking behind } \\
\text { the shadows. }\end{array}$ \\
\hline
\end{tabular}

The writer also used a procedure translation that is mentioned by Vinay and Darbelnet (1958) namely Equivalence procedure. the translator used this procedure because like Vinay and Darbelnet said that equivalence as something almost inherently cultural, using the example someone expressing an emotional. Equivalence is also related to idiomatic expression but translating literally would leave a reader confused. There are seven samples that used the Equivalence procedure. The following table is the sample list of using this procedure. It can be seen on the Table 23 below.

Table 23.

The example of using Equivalence procedure

\begin{tabular}{|c|l|l|}
\hline No. & $\begin{array}{c}\text { Source } \\
\text { Language }\end{array}$ & Target Language \\
\hline 1. & Wah, & Gee, \\
\hline
\end{tabular}




\begin{tabular}{|c|l|l|}
\hline 2. & Woaaahh & Wooww \\
\hline 3. & $\begin{array}{l}\text { Mehmet, } \\
\text { awas! }\end{array}$ & Mehmet, look out \\
\hline 4. & Hmm & Umm \\
\hline
\end{tabular}

The reformulation of text. The first and second process of translation had been done, so the next process is the reformulation of text. In this phase, the text translated using method and some procedures that restructured the texts become the good texts that understandable and readable easily by the target readers.

The obstacle of doing this process was happened when reading the result but the texts was quite awkward and weird, because, sometimes between the texts and the pictures were not coherence. Nonetheless, this problem was not too difficult in doing the text reformulation.

In this process, there are several results that have been translated. Among many revisions of result that had been made, three samples of the result revisions were took and those are inserted into the table below. The first result in the left side is the text that translated by herself. The second result in the middle side is the text that was proofread by friends; Haby Syauqi and Feldi Sandria. Then, the third result in the right side is the text that was checked and revised by the supervisor.

Table 24.

The comparison of translation result

\begin{tabular}{|c|c|c|}
\hline $\begin{array}{l}1^{\text {st }} \text { result of } \\
\text { translation }\end{array}$ & $\begin{array}{c}2^{\text {nd }} \text { result of } \\
\text { translation }\end{array}$ & $\begin{array}{l}3^{\text {rd }} \text { result of } \\
\text { translation }\end{array}$ \\
\hline $\begin{array}{l}\text { The } \\
\text { Conquest of } \\
\text { Constantino } \\
\text { ple was a big } \\
\text { event that } \\
\text { jolted the } \\
\text { east and the } \\
\text { west. This } \\
\text { event has } \\
\text { been told by } \\
\text { Rasulullah s } \\
\text { ince } \\
\text { thousands } \\
\text { years ago } \\
\text { and came } \\
\text { true in } 1453 \text {. } \\
\text { A conqueror } \\
\text { who made it } \\
\text { come true } \\
\text { was a young } \\
\text { man who } \\
\text { promised by } \\
\text { Rasulullah ; } \\
\text { Sultan } \\
\text { Muhammad } \\
\text { al-Faateh. }\end{array}$ & $\begin{array}{l}\text { The } \\
\text { Constantino } \\
\text { ple } \\
\text { conquering } \\
\text { was a big } \\
\text { event that } \\
\text { jolted the } \\
\text { east and the } \\
\text { west. } \\
\text { Rasulullah } \\
\text { has told this } \\
\text { event since } \\
\text { thousands } \\
\text { years ago } \\
\text { and then } \\
\text { came true in } \\
\text { 1453. A } \\
\text { conqueror } \\
\text { who made it } \\
\text { come true } \\
\text { was a young } \\
\text { man who } \\
\text { had promised by } \\
\text { Rasulullah } \\
\text { Sultan } \\
\text { Muhammad } \\
\text { al-Faateh. }\end{array}$ & $\begin{array}{l}\text { The } \\
\text { Conquest of } \\
\text { Constantino } \\
\text { ple was a big } \\
\text { event that } \\
\text { jolted the } \\
\text { East and the } \\
\text { West. This } \\
\text { event has } \\
\text { been told by } \\
\text { Rasulullah s } \\
\text { ince } \\
\text { thousands } \\
\text { years ago } \\
\text { and came } \\
\text { true in 1453. } \\
\text { A conqueror } \\
\text { who made it } \\
\text { come true } \\
\text { was a young } \\
\text { man who } \\
\text { had been } \\
\text { promised by } \\
\text { Rasulullah ; } \\
\text { Sultan } \\
\text { Muhammad } \\
\text { al-Faateh. }\end{array}$ \\
\hline
\end{tabular}

\section{IV.CONCLUSION}

The title of this final project is Translating "Muhammad Al-Fatih: Perang Varna"Comic by Handri Satria from Bahasa Indonesia into English. This comic was written by Handri Satria who an comic writer from Indonesia. He made this comic based on the history of Conquering Constantinople city. This comic is really good to be read. It is like an educating comic in which many lessons can be gotten by reading this comic. Therefore, one of the aims of making this final project is to add the collection of Islamic comic for the readers.

Based on the experience in translating this comic, there are some main problems that need to be evaluated. The first problem is the difficulty of word equivalence between the SL and the TL word. Sometimes, because of this problem the wrong word was chosen and made the translation a little bit weird to be read. Fortunately, in solving this problem some dictionaries were used to help in translating namely Longman Advance Dictionary, IndoDic E-dictionary 1.2,Oxford Dictionary English pro Offline and Oxford World History Dictionary. Beside of that, in solving this problem, reading articles in internet was also the solution. Some article were used www.militaryarchitecture.comand

www.greatistanbul.com/conquest.html. These solutions are quite helping to find the right words and make the result of translation good to be read.

The second problem is the difference of culture and language style between SL and TL. The culture and language style of text must be noticed carefully. A translator must know how to transfer the language and keep the sense from SL into TL without change the meaning of the text. Therefore, the solution of this problem is reading the text in several times. Since the story of this comic is a history, so, the similar text or article that related with this comic can be found in the another source. By reading the similar text, the translator has more adequate knowledge and insight about the text and can translate the text from SL into TL without change the message, the meaning, the sense of situation, and the culture that are existed in the comic.

In typesetting process, there were some applications that were used to help in changing the comic become a new version namely PhotoScape 3.6.2, Paint 1511, and PhotoShop CS6. These applications were very usefull in doing typeset. By using these applications the comic translation was easier to be completed to get the new version of comic. To use these applications are quite difficult for a beginner, because so many tools that have to be understood. For me, it was quite easy, because I am quite often to use these applications.

\section{REFERENCES}


[1] Azry, Ashobta.2012. Tentang Typeset Translate Cleaning. Retrieved on August02, 2017http://www.apa-itu-raw-typeset-translatecleaning.com

[2] Bell, Roger.T.1991.Translation and Translating: Theory and Practice. UK. Longman.

[3] Brodo,M.(2014). Multimodality, translation and comics Article in Perspectives Studies in Translatology. Retrieved on August 02, 2017 http://www.tandfonline.com

[4] Catford,J.C.1969. A Linguistic Theory of Translation. London: Oxford University Press.

[5] Duckett,Bob. 2007. Longman Advance American Dictionary.

[6] Frederik.L.S.(2016). Translating Manga. Retrieved on August 02, 2017 www.worldliteraturetoday.org/2016/march.translatingmangafrederik-l-schodt Furuhata-Turner. Hamako.'The Use of Japanese manga as a Learning Tool To Teach Translation". Journal.

[7] Larson, Mildred L. 1984. Meaning Based Translation. University Press of America.

[8] Lusiana, W. N. 2006. An Analysis of Translation Strategies Used in Indonesian Comic Translation of the Adventure of Tintin: The Black Island to Pulau Hitam and King Ottokar's Sceptre to TongkatRaja Otokar. Semarang: Universitas Dian Nuswantoro.

[9] Military Architecture Official.Retrieved on August 02, 2017 www.militaryarchitecture.com?index.php/Fortifications/the-wallsofconstantinople.html
[10] Newmark, Peter. 1988. Approaches to Translation. UK: Prentice Hall.

[11] Nida, E. A. and Charles. R. Taber. 1974. The Theory and Practice of Translation. Leiden: J. E. Brili.

[12] Shadily, Hasan and John M. Echold. 1989. Kamus Inggris Indonesia. Jakarta: PT. Gramedia.

[13] Suryoalam, A. T. 2011. "A Study of Translation Strategies Used in Comic Translation of Lucky Luke: The Bridge on The Mississippi To Lucky Luke: Jembatan Mississippi”.Undergraduate Thesis. English Department,

[14] Faculty of Languages and Letters, Dian Nuswantoro University. Walinski. (2015). The Translation Procedure. Retrieved on August 06,2017 http://www.tandfonline.com

[15] Website of Istanbul.2006. Retrieved on August 04, 2017 www.greatistanbul.com/conquest.htm

[16] WhatIsQuran Website. Retrieved on August 02, 2017 http://whatisquran.com?1132-muhammad-al-fatih-the-conquerorofconstantinople.html

[17] Yanti. H. 2013. "The Process of Translating Princess Muslimah Story Book fromBahasa Indonesia into English”. Final Report. English Department, State Polytechnic of Padang.

[18] Zanettin. Federico.(2008). Comic in Translation Manchester St Jerome Publishing. Retrieved on August 02, 2017 www.academia.edu/865483/zanettin_F._ed._2008_Comics_in_Trans lation_Manchester 